\title{
The East River tidal strait, New York City, New York, a high-nutrient, low-chlorophyll coastal system
}

\author{
Yaqin Li $[$ · Shannon L. Meseck • Mark S. Dixon · Gary H. Wikfors
}

Received: 7 June 2017 / Accepted: 29 January 2018/Published online: 17 February 2018

(C) The Author(s) 2018. This article is an open access publication

\begin{abstract}
The East River tidal strait, located between New York Harbor and Western Long Island Sound, is characterized by high suspended silt concentrations with low organic content kept in suspension by intense tidal currents. Inorganic nutrients, including nitrate, nitrite, ammonia, and phosphate, were high even during the summer. Dissolved inorganic nitrogen (DIN) concentrations generally were above $20 \mu \mathrm{M}$ and did not likely limit phytoplankton growth. Despite high nutrient concentrations, median chlorophyll $a$ concentration was only $1.53 \mu \mathrm{g} \mathrm{l}^{-1}$, making the East River tidal strait a high-nutrient, low-chlorophyll (HNLC) area, likely a result of suspended silt blocking light penetration into the surface water. There were times at which the ratio of mixed layer to depth of the euphotic zone was generally greater than what has been suggested for phytoplankton to produce net primary production. The high-nutrient East River tidal strait is likely one of the sources of nutrients fueling summer phytoplankton production and consequent hypoxia in the Western Long Island Sound as silt settles from surface water in the lower turbulence conditions of the western narrows of Long Island Sound, thereby allowing light penetration and subsequent consumption of dissolved nutrients by phytoplankton.
\end{abstract}

Keywords High-nutrient · Low-chlorophyll · East River tidal strait · Western Long Island Sound · Water quality

\section{Introduction}

The East River tidal strait (referred to simply as the 'East River' in some references and maps) is a water body with a length of about $25 \mathrm{~km}$ connecting New York Harbor to the east to Western Long Island Sound to the west (Fig. 1); thus, it is not a true river. As a "tidal strait," the East River receives little fresh water input compared to conventional rivers. The East River tidal strait is divided into upper and lower sections by the Hell Gate sill where the tidal flow is restricted through a narrow passage (Marmer 1935). The upper East River tidal strait, from the Hell Gate to Willets Point near Western Long Island Sound, $13.5 \mathrm{~km}$ in length, is shallower and wider than Hell Gate. The lower East River tidal strait, $\sim 12 \mathrm{~km}$, from Hell Gate to the Battery

Electronic supplementary material The online version of this article (https://doi.org/10.1007/s40071-018-0189-2) contains supplementary material, which is available to authorized users.

Y. Li $(\bowtie) \cdot$ S. L. Meseck · M. S. Dixon · G. H. Wikfors

NOAA, National Marine Fisheries Service, Northeast Fisheries Science Center, Milford Laboratory, Milford, CT 06460,

USA

e-mail: judy.yaqin.li@noaa.gov 


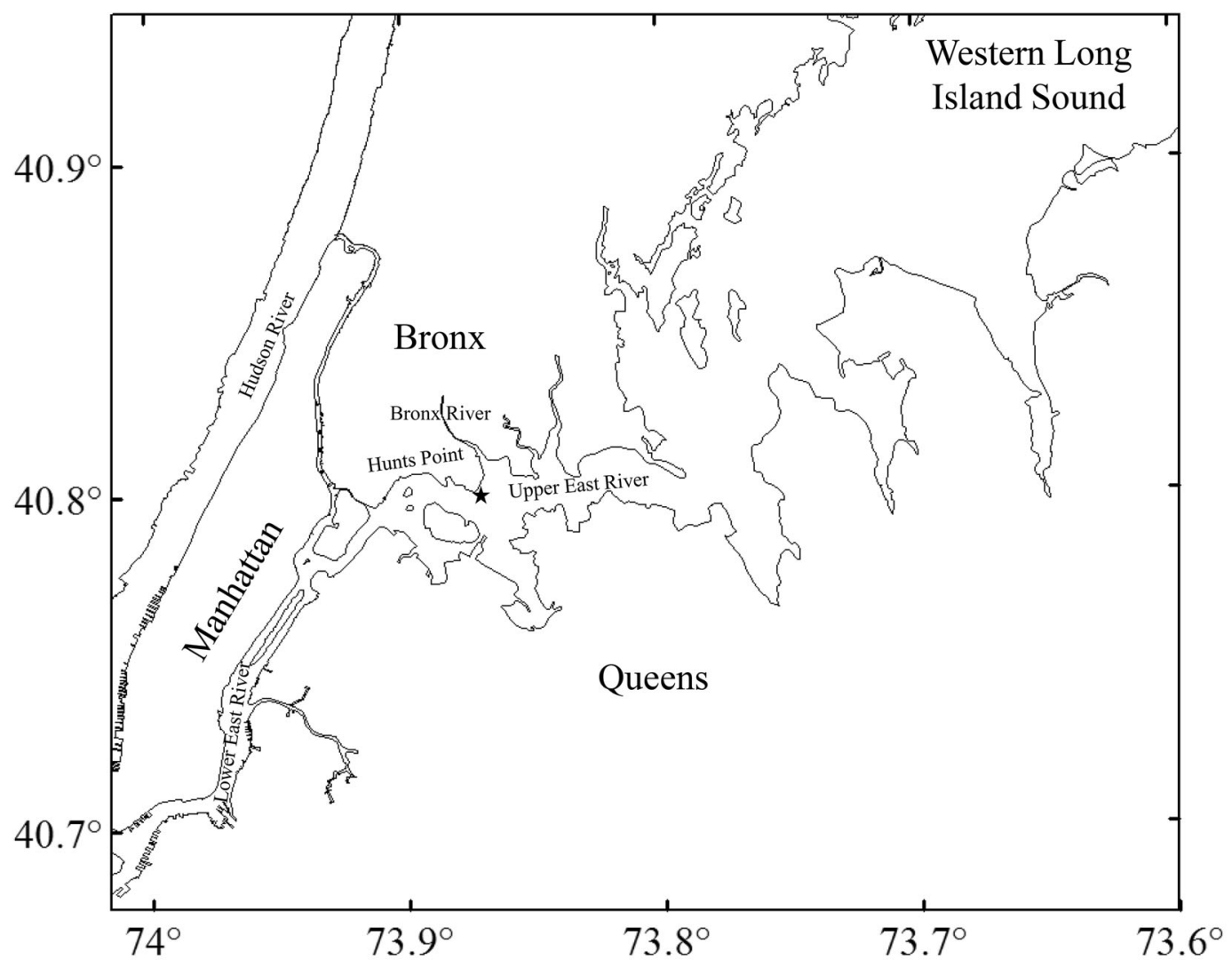

Fig. 1 Map of the study site located at $40^{\circ} 48^{\prime} 5.99^{\prime \prime} \mathrm{N}, 73^{\circ} 52^{\prime} 17.76^{\prime \prime} \mathrm{W}$, off Hunts Point, Bronx, New York

where the Hudson River enters the New York Harbor, is narrower and deeper (Bowman 1976). The flow in the East River tidal strait is tidally dominated, with a semidiurnal pattern resulting from the superposition of the Long Island Sound and New York Harbor tidal waves (Bowman 1976; Blumberg and Pritchard 1997). In the lower East River tidal strait, the tidal current is swift and can reach as high as $3 \mathrm{~m} \mathrm{~s}^{-1}$ near Hell Gate (Bowman 1976). In the upper East River tidal strait, the current is slower but still reaches $1 \mathrm{~m} \mathrm{~s}^{-1}$. Within the East River tidal strait, there is a two-layered flow with a near-surface transport toward Long Island Sound and transport at depth toward the New York Harbor. Overall net water transport is thought to be toward the Sound (Bowman 1976; Browning et al. 2014). In the upper East River tidal strait, the water is turbid with high concentration of inorganic materials in the total suspended seston, but very low particulate organic matter or chlorophyll (Galimany et al. 2013). Little information, however, is available concerning phytoplankton, light availability, and other relevant environmental variables to understand if the system is able to produce net primary production.

Most coastal areas, particularly those that are highly populated, are subject to high nutrient loading (e.g., Varekamp et al. 2014). With high nutrients, high phytoplankton abundance is common (e.g., Nixon 1995). In the turbid coastal environment, however, light can become the factor limiting phytoplankton growth and primary productivity (Grobbelaar 1985; Cloern 1987; Irigoien and Castel 1997; Domingues et al. 2011b; Gameiro et al. 2011). Phytoplankton may be limited by the light part of the year or year-round (Kromkamp et al. 1995; Kocum et al. 2002; Domingues et al. 2011b). In nutrient-rich, turbid environments, primary productivity may be directly proportional to the availability of light (Underwood and Kromkamp 1999; Domingues et al. 2011a). Thus, in very turbid environments, high nutrients do not necessarily lead to high phytoplankton abundance (Irigoien and Castel 1997). Phytoplankton may adapt to low light conditions, whether caused by high turbidity or low incident light (Grobbelaar 1985; McMinn et al. 2010), with increased photosynthetic efficiency. Estuaries, such as the Chesapeake Bay, Delaware Bay, and San Francisco Bay (Cole 
and Cloern 1984; Harding et al. 1986), have areas within them that are typically classified as high nutrient low chlorophyll-a (HNLC) attributed to high turbidity.

We characterized nutrient and seston conditions in the upper East River tidal strait. We report here phytoplankton, inorganic nutrients, euphotic zone depth, phytoplankton potential maximum photosynthetic efficiency, and other environmental variables. As coastal areas tend to exhibit high temporal variability over a short (day) and long term (e.g., seasonal and inter-annual), we conducted high-frequency measurements of some environmental variables over spring-autumn seasons. Our results suggest that phytoplankton were at times not able to achieve net primary production despite high nutrient availability because of low light penetration. Our findings, combined with existing knowledge of tidal currents, offer insights into the nutrient dynamics of western Long Island Sound, an area in which symptoms of eutrophication prevent achievement of water-quality standards.

\section{Materials and methods}

Study site

The sampling station at the upper East River tidal strait is located at $40^{\circ} 48^{\prime} 5.99^{\prime \prime} \mathrm{N}, 73^{\circ} 52^{\prime} 17.76^{\prime \prime} \mathrm{W}$, off Hunts Point, Bronx, New York (Fig. 1). It is in the highly industrialized section of New York City. The site is within close proximity to the Hunts Point Wastewater Treatment Plant, one of the largest wastewater treatment plants in New York City. The upper East River tidal strait reportedly has varied depth. The depth near Hunts Point, at Clarkson Point/College Point is between $15 \mathrm{~m}$ on the south Channel and $24 \mathrm{~m}$ at the center of the channel (Blumberg and Pritchard 1997). The Department of Environmental Protection of the State of New York has conducted a year-round, water-quality survey in the area in recent years. They reported that a station (E14) near this study site is well mixed and has a mean depth of $6.5 \mathrm{~m}$ (http://www.nyc.gov/html/dep/html/har borwater/harbor_water_sampling_results.shtml).

Water chemistry measurements

Water samples were collected weekly from April 2012 to October 2012 from $0.5 \mathrm{~m}$ below the surface for major nutrients (including nitrate plus nitrite, ammonium, and phosphate), chlorophyll $a$, and total suspended solids. Chlorophyll $a$ was measured fluorometrically. Sample filtration and extraction followed Li et al. (2009), and fluorescence intensity was measured by a Perkin Elmer Plate reader following Li et al. (2013). In short, a known amount of water (generally $500 \mathrm{ml}$ ) was filtered through a GF/F glass fiber filter immediately after collection. Filters were kept on ice until transported to the lab where they were stored at $-20{ }^{\circ} \mathrm{C}$ until analyses. Immediately prior to analyses, filters were sonicated in $90 \%$ acetone with a Tekmar Sonic Disruptor. The sonicated solutions were kept refrigerated overnight to allow for pigment extraction. Samples then were centrifuged at $8000 \times g$ for $10 \mathrm{~min}$. A 300- $\mu \mathrm{l}$ supernatant sub-sample was pipetted into a 96-well plate well. Samples were read at $690 \mathrm{~nm}$ by a PerkinElmer Luminescence Spectrometer LS 50B (PerkinElmer inc., Waltham, MA, USA). The regression between fluorescence and chlorophyll $a$ was calibrated with a chlorophyll $a$ standard from Sigma-Aldrich Co. LLC. (St. Louis, MO, USA).

Nutrient samples were taken with protocols detailed by Meseck et al. (2012). Briefly, $120 \mathrm{ml}$ of water was filtered through a pre-combusted $\left(450{ }^{\circ} \mathrm{C}\right.$ overnight), $25-\mathrm{mm} \mathrm{GF} / \mathrm{F}$ filter placed in a low-pressure, syringefilter holder. The filtered water was stored in a cooler with ice until analysis at the laboratory.

Total ammonia, phosphate, silicate, and nitrate plus nitrite were determined using a Quattro Auto Analyzer (Seal Analytical, WI, USA). Detailed descriptions for quantifying total ammonia, nitrate plus nitrite, phosphate, and silicate using this instrument can be found in Methods of Seawater Analysis (Hansen and Koroleff 1999). Briefly, total ammonia was determined using the Berthelot reaction (detection limit, $0.05 \mu \mathrm{M}$ ). For nitrate plus nitrite, a cadmium column was used to reduce nitrate to nitrite, and then the formation of the red azo dye was used (detection limit $0.005 \mu \mathrm{M}$ ). The formation of $\beta$-silicomulybic acid was used to determine silicate (detection limit $0.1 \mu \mathrm{M}$ ), and a phosphomolybdate hetropoly acid reduced to a blue compound was used to determine phosphate (detection limit $0.01 \mu \mathrm{M}$ ). 
Urea determinations were done following the method of Goeyens et al. (1998). Briefly, the method involves the formation of imidazolone-thiosemicarbazide complex at room temperature for $72 \mathrm{~h}$. The detection limit is $0.10 \mathrm{uM}$ with $1.6 \%$ reproducibility.

Total suspended solids (TSS) samples were collected on $25 \mathrm{~mm}$ pre-weighed and combusted Gf/F filters. Samples were put immediately at $-20{ }^{\circ} \mathrm{C}$ until analysis. Samples were then dried at $60{ }^{\circ} \mathrm{C}$ and weighted.

Continuous, high-frequency measurements of environmental variables

Temperature, salinity, dissolved oxygen, chlorophyll $a, \mathrm{pH}$, turbidity, and under-water PAR (photosynthetically available radiation) were measured in situ by sensors attached to a YSI 6600 V2-4 Sonde (YSI Inc., Yellow Springs, OH, USA) suspended about $0.5 \mathrm{~m}$ below the surface from a moored raft. All of the sensors attached to the Sonde took a reading every $15 \mathrm{~min}$. The data collections were from April to October 2012, with gaps plotted on Fig. 4. Sensor models used were as follows: temperature and salinity (combined), 6360; dissolved oxygen, $\mathrm{ROX}^{\mathrm{TM}}$; chlorophyll $a, 6025$; $\mathrm{pH}, 6561$; turbidity, 6136; under-water PAR, $2 \pi$ quantum sensors (model: LI-192) by LI-COR ${ }^{\circledR}$ (LI-COR ${ }^{\circledR}$, Lincoln, Nebraska USA). The top PAR sensor was $0.5 \mathrm{~m}$ below the water surface and the bottom one was at $1 \mathrm{~m}$ below the surface. Sensor calibration and maintenance followed the recommendation of the manufacturer. Non-photochemical quenching of chlorophyll $a$ fluorescence during the day resulted in chlorophyll $a$ calculated values underestimated from the in situ fluorescence (Dandonneau and Neveux 1997; Chekalyuk and Hafez 2008). Accordingly, data corrections were made following $\mathrm{Li}$ et al. (2012).

Phytoplankton identifications

Each 100-ml water sample was fixed in 2\% acidic Lugol's solution (Throndsen 1978) and stored in an amber glass bottle until analyses. A 50-ml sub-sample was settled following the standard Utermöhl settling chamber method (Hasle 1978) and examined with a Zeiss Axio inverted microscope (Carl Zeiss Microscopy, LLC, Thornwood, NY, USA).

Photosynthetic variables

The FIRe (Fluorescence Induction and Relaxation) System (by Satlantic Inc., Halifax, Canada) was used for variable chlorophyll fluorescence measurements twice a month from May to October 2012. FIRe is based upon the Fast Repetition Rate Fluorometry (FRRF) technique. Water samples collected from the study site $(0.5 \mathrm{~m}$ below the surface) were kept in the dark at ambient water temperature for at least 20 min before measurements. $F_{\mathrm{v}} / F_{\mathrm{m}}$, maximum quantum efficiency or maximum quantum yield of PSII, was calculated through the built-in instrument protocol.

Euphotic zone depth calculations

The depth of euphotic zone, Zeu, taken as the depth to which $1 \%$ of the surface light penetrates, was calculated two ways: first from the measurements of the two under water PAR sensors following the equation:

$$
I_{\mathrm{z}}=I_{0} \times e^{-\mathrm{kz}}
$$

in which $k$ is the vertical extinction coefficient, and $z$ equals the vertical distance between $I_{\mathrm{z}}$ and $I_{0}$, which represent irradiance at depth $\mathrm{z}$ and the surface, respectively. A daily median Zeu was then calculated based on data from 10:00 am to 2:00 pm.

Secondly, Zeu was calculated from Secchi disk depth measured twice monthly at the site. Zeu was 3.5 times of the secchi disk depth based on Holmes (1970). 
Statistical analyses

To test the influence of tide upon the water variables, correlations were calculated between the individual variables and the tidal heights using Statgraphics Plus. Tidal heights were based upon NOAA tidal predictions at station Kings Point, approximately $10 \mathrm{~km}$ east of the study site. The NOAA table provided height at only 4 time points on each date; therefore, the gaps between these time points were filled assuming a sine function for the tidal heights. To focus on the tide and minimize the other variations, such as day-to-day or seasonal variations, the sampling time series was broken into 5 seasonal periods based upon water temperature. Pearson correlations between water variables and tidal heights were calculated for each of the 5 periods (Table 1).

\section{Results}

Total suspended solids (TSS) from April to October ranged from 7.73 to 46.93 with a median of $19.30 \mathrm{mg} 1^{-1}$ (Fig. 2). April to June had higher TSS than the rest of the months, with a median of $27.65 \mathrm{mg}^{-1}$. Median TSS from July to October was $15.83 \mathrm{mg} \mathrm{l}^{-1}$.

In terms of dissolved nutrients, the highest nitrate concentration was $34.71 \mu \mathrm{M}$, with a median of $14.01 \mu \mathrm{M}$ (Fig. 3). There were 3 occasions during July-August when one or more dissolved nitrogen species was below the method detection limit. The highest ammonia was $43.19 \mu \mathrm{M}$, with a median of $23.90 \mu \mathrm{M}$. The total inorganic nitrogen (TIN) (nitrate, nitrite and ammonia combined) ranged from 15.23 to $73.84 \mu \mathrm{M}$ from April to October. This range of TIN is high, particularly for the summer when most temperate, coastal areas experience undetectable or low TIN. Urea was also fairly high, with a maximum of $27.19 \mu \mathrm{M}$; the concentration never went below the detection limit. There also were fairly high concentrations of dissolved phosphate and silica in the water, ranging from 2.58 to $14.17 \mu \mathrm{M}$ and 21.94 to166.72 $\mu \mathrm{M}$ for phosphate and silicate, respectively.

Seasonal changes in temperature and other environmental variables at the site are presented in Fig. 4. 96-point $(24 \mathrm{~h})$ moving averages were used to remove diel fluctuations. Temperature showed a seasonal warming from April to late August and a gradually decreasing trend afterwards. Salinity ranged from 22.11 to 27.43. The relatively small fluctuation in salinity is consistent with the fact that the upper East River tidal strait has limited freshwater input. Chlorophyll $a$ ranged from 0.2 to $4.6 \mu \mathrm{g} 1^{-1}$ with a median value of $1.53 \mu \mathrm{g}^{-1}$. Dissolved Oxygen (DO) ranged from 2.15 to $9.66 \mathrm{mg}^{-1}$.

Table 1 Correlations between tidal height and other variables

\begin{tabular}{llccrrr}
\hline Time period & Statistics & \multicolumn{2}{l}{ Variables } & & & \\
\cline { 2 - 6 } & & Temperature & Salinity & pH & DO (mg $\left.1^{-1}\right)$ & Chl $a$ \\
\hline 25/4/12 to 31/5/12 & Pearson correlations & 0.014 & 0.025 & -0.118 & 0.048 & -0.108 \\
(Temperature increased) & $P$ value & 0.107 & 0.107 & $<0.001$ & 0.005 & $<0.001$ \\
& Covariances & 0.016 & 0.016 & -0.006 & 0.031 & 0.052 \\
31/5/12 to 19/6/12 & Pearson correlations & 0.165 & -0.337 & -0.236 & -0.048 & -0.197 \\
(Temperature increased) & $P$ value & $<0.001$ & $<0.001$ & $<0.001$ & 0.002 & $<0.001$ \\
& Covariances & 0.156 & -0.235 & -0.014 & -0.019 & -0.150 \\
20/6/12 to 10/7/12 & Pearson correlations & 0.341 & -0.437 & -0.318 & 0.051 & -0.143 \\
(Temperature stable) & $P$ value & $<0.001$ & $<0.001$ & $<0.001$ & 0.022 & $<0.001$ \\
& Covariances & 0.206 & -0.181 & -0.0083 & 0.011 & -0.134 \\
12/7/12 to 26/7/12 & Pearson correlations & 0.539 & -0.441 & 0.009 & 0.455 & -0.109 \\
(Temperature increased) & $P$ value & $<0.001$ & $<0.001$ & 0.73 & $<0.001$ & $<0.001$ \\
& Covariances & 0.222 & -0.195 & 0.001 & 0.360 & -0.085 \\
29/8/12 to 27/9/12 & Pearson correlations & 0.008 & -0.334 & 0.106 & 0.263 & -0.022 \\
(Temperature decreased) & $P$ value & 0.680 & 0.083 & $<0.001$ & $<0.001$ & 0.430 \\
& Covariances & 0.006 & -0.029 & 0.007 & 0.095 & -0.018 \\
\hline
\end{tabular}




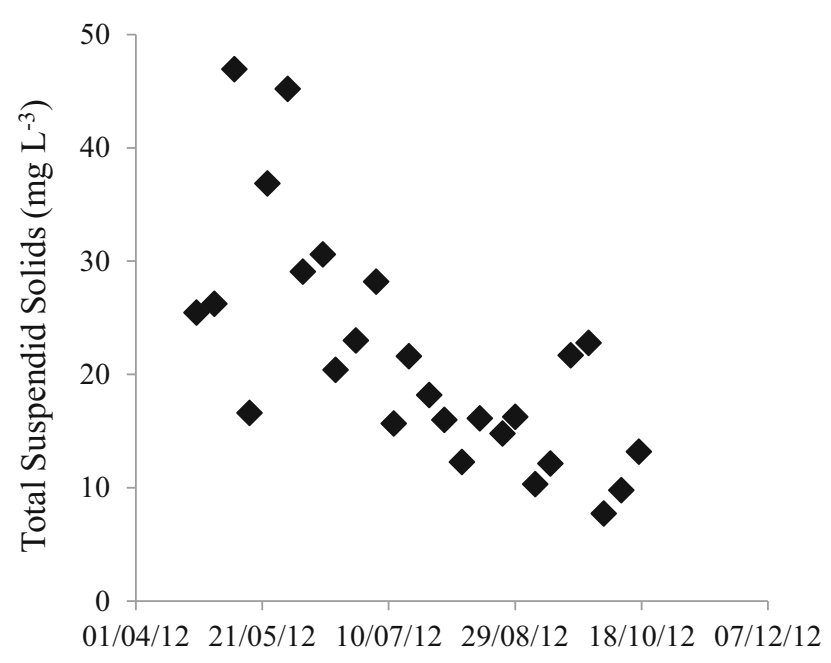

Fig. 2 Total suspended solids at the site

In addition to the seasonal changes in the environmental variables, there was also short-term variability revealed by plotting raw, un-averaged data (Figs. 5, 6). Water temperature, $\mathrm{pH}$, and dissolved oxygen generally exhibited two highs and two lows daily.

Water temperature was positively correlated with tidal height from 31 May to 26 July (Table 1). Salinity was negatively correlated with the tidal height except for the period from 25 April to 31 May (Table 1) when rain in the spring may have upset the correlation. A negative rather than positive relationship between salinity and tidal height is consistent with water circulation in the East River tidal strait, which includes a net flow from New York Harbor toward the Western Long Island Sound. New York Harbor has lower salinity (influenced by the Hudson River) than western Long Island Sound. Correlation between $\mathrm{pH}$ and tidal height was not consistent between different time periods (Table 1); a negative correlation in the spring and early summer was replaced by a positive correlation in the summer to early fall. Dissolved oxygen showed consistent positive correlation with tidal height (Table 1). Chlorophyll $a$ had a consistent negative correlation with tidal height (Table 1).

To focus specifically on the diel patterns of dissolved oxygen (DO) and $\mathrm{pH}$, data from 7 June to 13 June were selected when day-to-day variation was small. $\mathrm{DO}$ and $\mathrm{pH}$ showed the same diel variation with two daily peaks and two valleys (Fig. 6).

The phytoplankton community was dominated by diatoms, which made up more than $70 \%$ of the community, numerically. The most common species were: Skeletonema costatum, Thalassiosira spp., Thalassiosira nordenskioldii, Thalassionema nitzschioides, Asterionella japonica, and Chaetoceros spp. In addition to diatoms, the green algae Euglena spp. and Eutreptiella spp. were frequently in the water. The dinoflagellate Scrippsiella sp. was present in low numbers. The phytoplankton maximum photosynthetic efficiency of PSII, $F_{\mathrm{v}} / F_{\mathrm{m}}$, at the site ranged from $0.359 \pm 0.04$ to $0.552 \pm 0.051$ (Fig. 7).

The euphotic zone depth ranged from 1.3 to $7.9 \mathrm{~m}$, with a median of $3.8 \mathrm{~m}$ (Fig. 8). The values calculated from the measurement of underwater irradiance and Secchi disk depth agree well. It appears that light penetration was the lowest in June and July, with a median euphotic zone depth of $3.1 \mathrm{~m}$. Light penetration increased late in the season in September and October, with a median euphotic zone depth of $6.1 \mathrm{~m}$.

\section{Discussion}

Suspended particular matter in the East River tidal strait was remarkably high. The highly turbid condition was attributable to inorganic matter, as the chlorophyll level at the site was fairly low with a median value of $1.53 \mu \mathrm{g} \mathrm{l}^{-1}$. This is in agreement with observations by Galimany et al. (2013) at the same site the previous year; this earlier study reported high suspended matter with low organic content. Galimany and co-workers attributed the high suspended solids at the site to tidal turbulence and Bronx River interactions with the East 

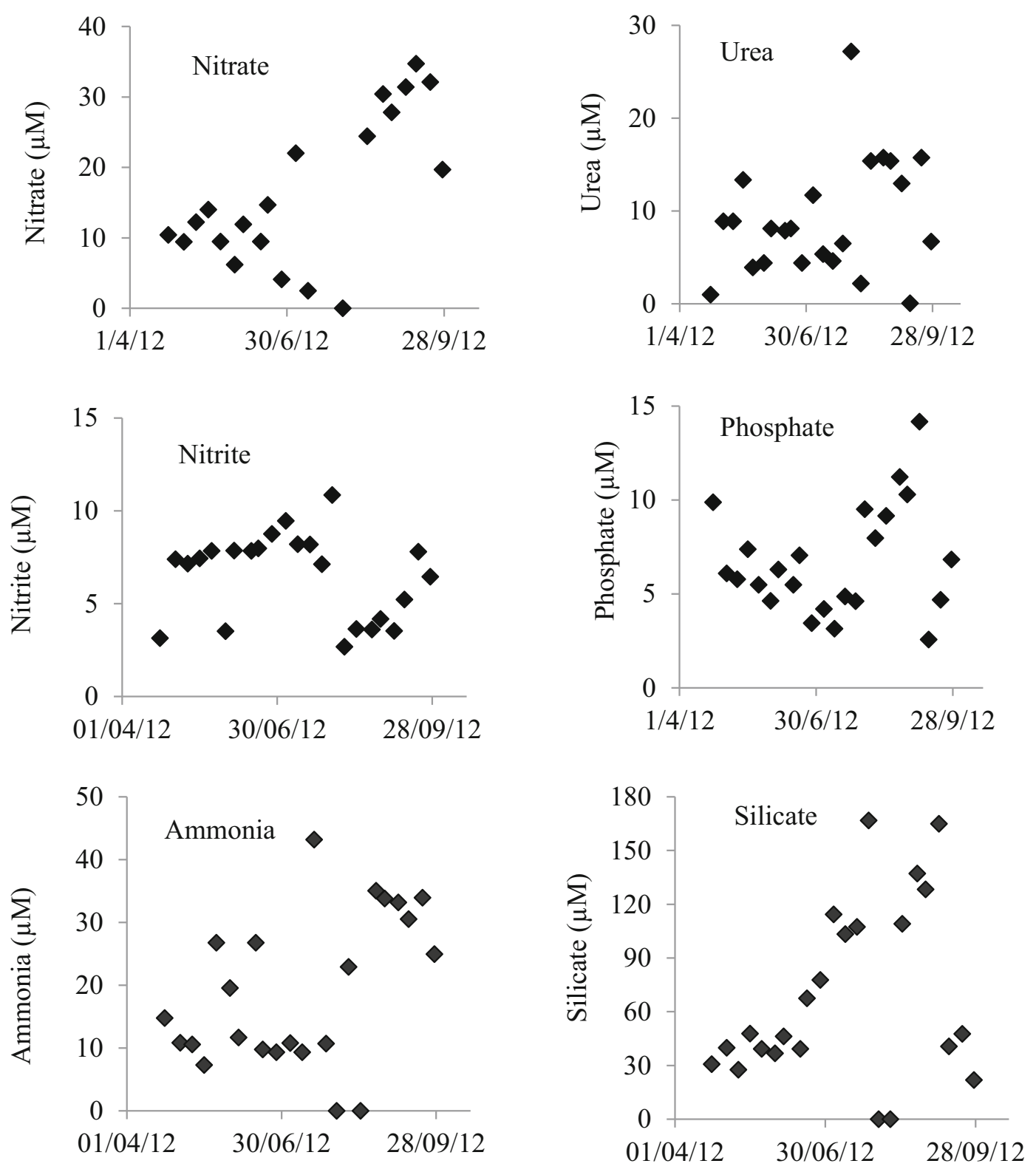

Fig. 3 Nutrients at the site from April 2012 to October 2012

River tidal strait. The swift tidal water movements at the East River tidal strait near our study site were documented by Bowman (1976), who reported a peak current speed of $3 \mathrm{~m} \mathrm{~s}^{-1}$ at the Hell Gate in the lower East River tidal strait and $1 \mathrm{~m} \mathrm{~s}^{-1}$ at the upper East River tidal strait close to our study site. Turbulent mixing of surface water at our study site was visually apparent at all times.

The phytoplankton community at the East River tidal strait site we studied was dominated by diatoms. The species composition was similar to that present in the adjacent western Long Island Sound (Capriulo et al. 2002; Lopez et al. 2014). One noticeable difference was the frequent presence of Euglena spp. and Eutreptiella spp. at the Hunts Point site. Although both Euglena and Eutrepiella were reported in the Long Island Sound, they were not in high numbers and not frequent (Capriulo et al. 2002; Liu and Lin 2008). Euglenoids can be associated with highly turbid conditions in an estuary (Pourafrasyabi and Ramezanpour 2014), possibly because this group is known to be mixotrophic (Yamane et al. 2001), and therefore, less dependent upon light than many other phytoplankters. 

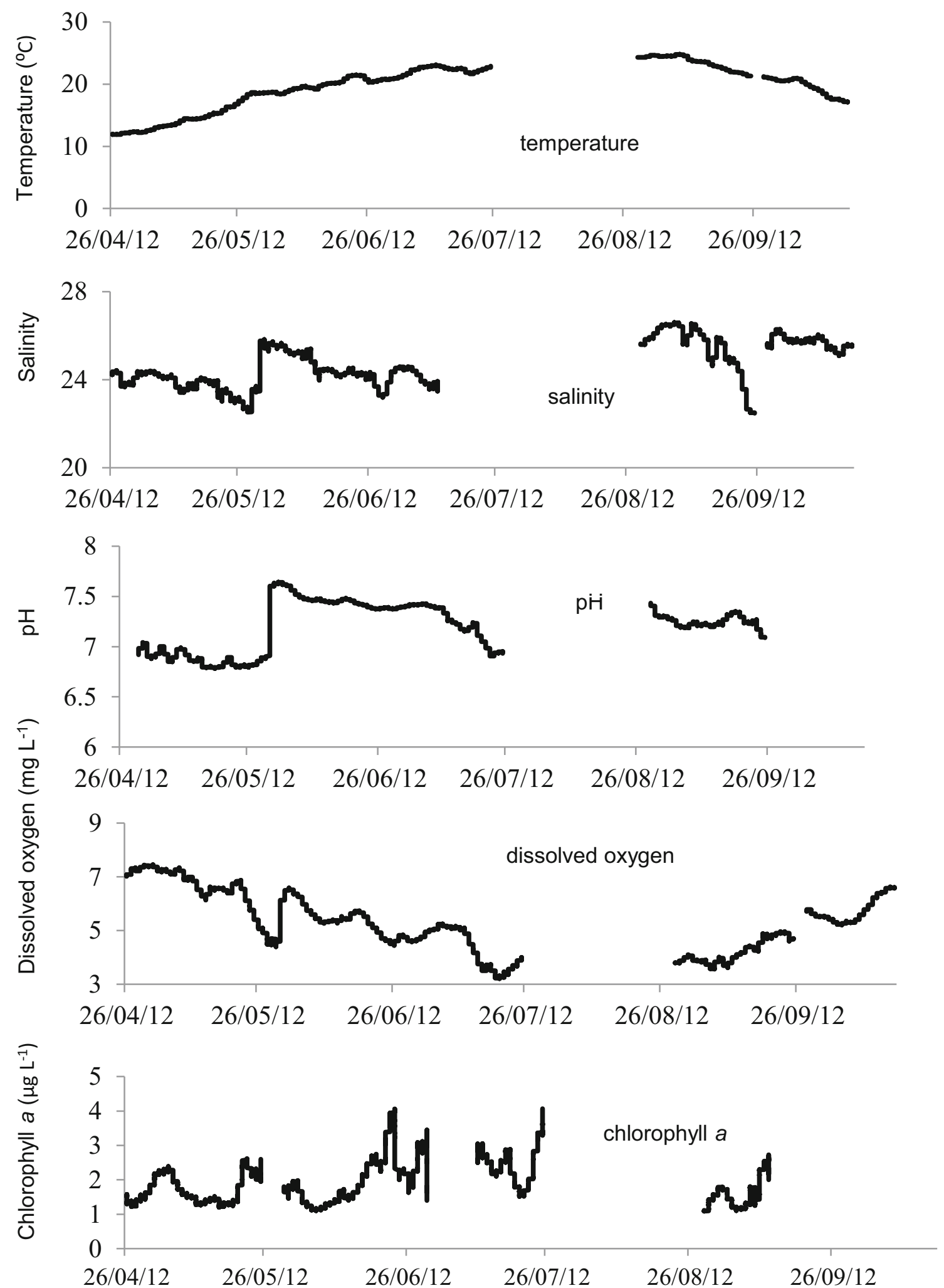

Fig. 4 Seasonal change in water variables at the site measured every $15 \min$ (96 readings daily). Data presented are 96-point moving average. Thus, the long-term change is shown without the diel signals 

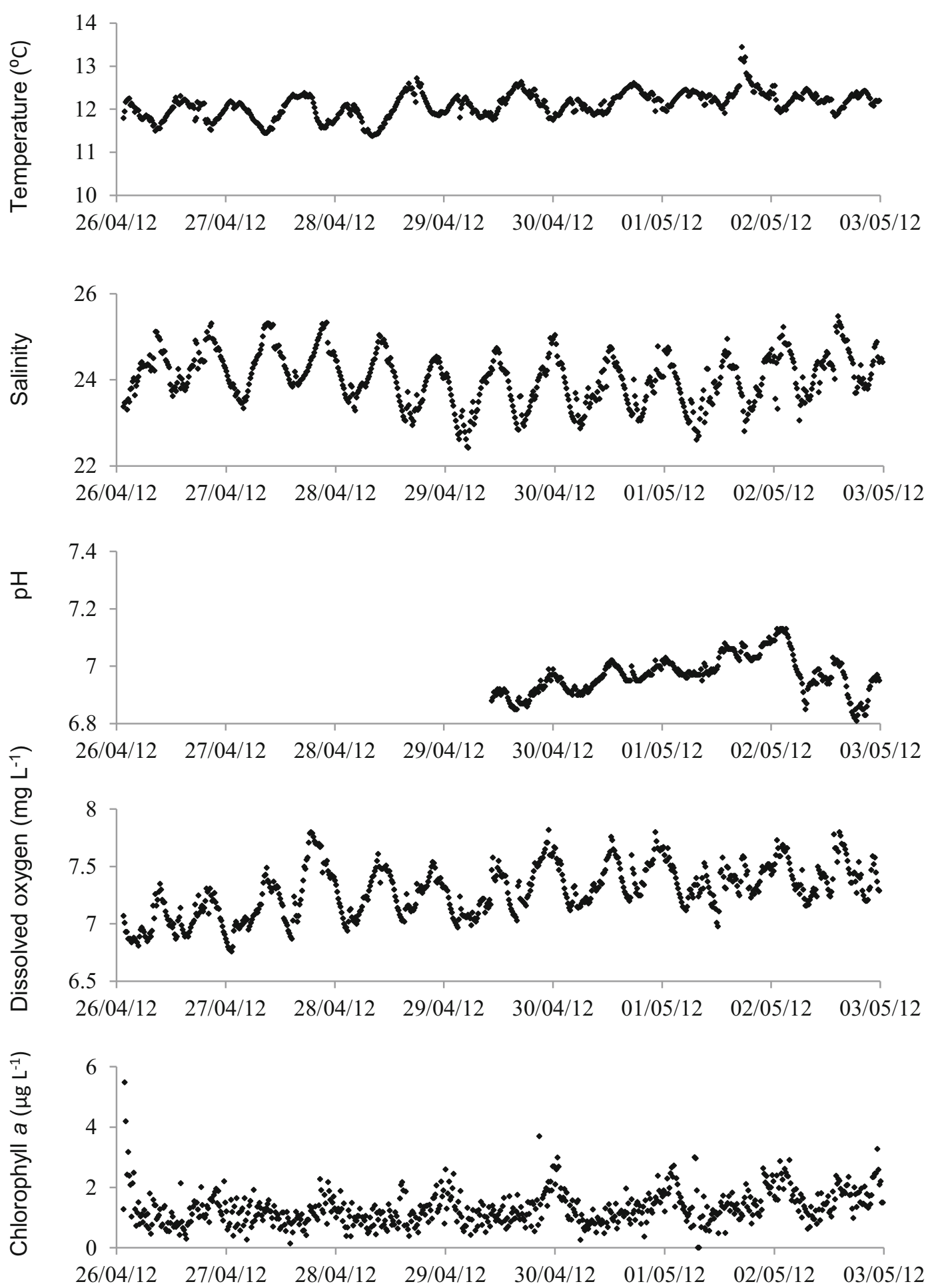

Fig. 5 Time series change in water variables at the site measured every $15 \mathrm{~min}$. Data presented are from 26/04/2012 to 3/05/2012

Phytoplankton $F_{\mathrm{v}} / F_{\mathrm{m}}$ in the East River tidal strait was lower compared to measurements in the Long Island Sound (personal communication with Matt Lyman, CT DEEP). $F_{\mathrm{v}} / F_{\mathrm{m}}$, a measure of photosynthetic efficiency of PSII, has been used as an indicator of general physiological stress. In the South Pacific Ocean, as well as in a HNLC (high nutrients low chlorophyll) equatorial upwelling region, reduction in Fv/Fm was related to iron limitation (Behrenfeld and Zbigniew 1999; Johnson et al. 2010). Goto et al. (2008) related changes in Fv/Fm 


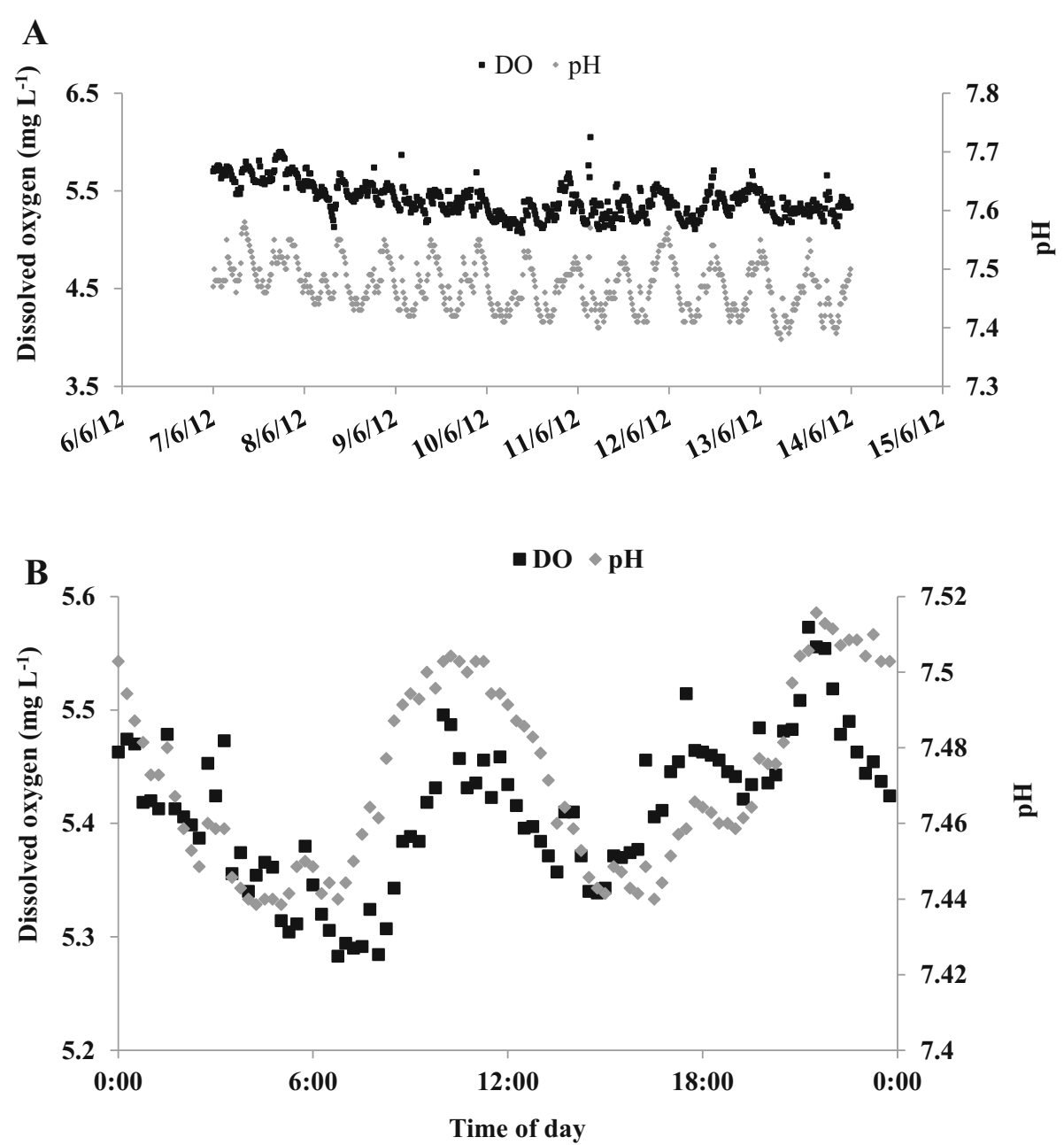

Fig. 6 Dissolved oxygen and pH at the site from June 72012 to June 13 2012. a Time series plots of data with 15 min-interval. b Mean diel cycle for the time period

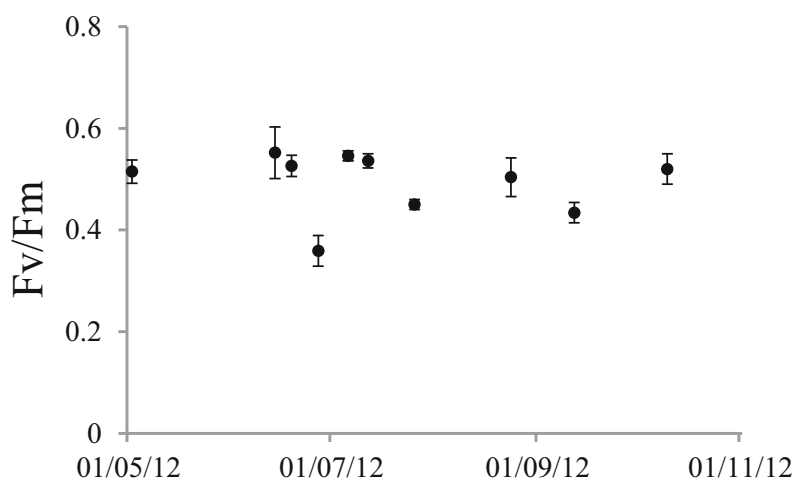

Fig. $7 \mathrm{Fv} / \mathrm{Fm}$ over time. Vertical bars represent one standard error of the mean

to the photo-damage of phytoplankton near the surface of lakes. Thus, low Fv/Fm in the East River Tidal strait likely indicated that the phytoplankton community in general was stressed.

In turbid estuaries, the ratio of mixed layer depth to euthotic zone depth $\left(Z_{\mathrm{m}} / Z_{\mathrm{eu}}\right)$ has been used to indicate if phytoplankton bloom is possible (e.g., Irigoien and Castel 1997). In San Francisco Bay, it was possible for phytoplankton to produce net primary production and for a bloom to initiate when $Z_{\mathrm{m}} / Z_{\mathrm{eu}}$ was less than 6 


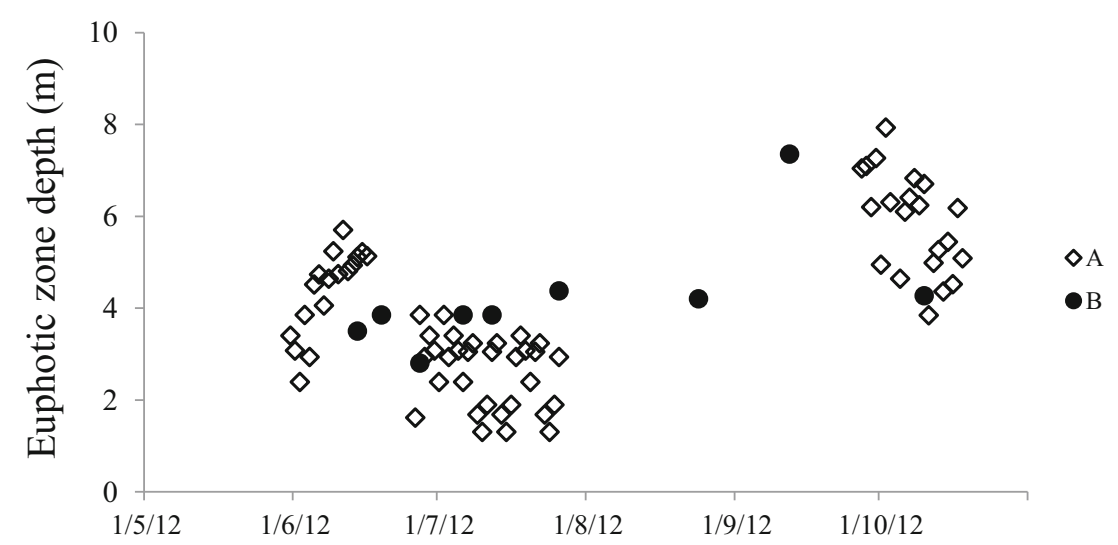

Fig. 8 Euphotic zone depth. a Daily median calculated from the under water PAR measured by the 2 sensors; $\mathbf{b}$ values calculated from the Secchi disk depth

(Cole and Cloern 1984; Alpine and Cloern 1988). It generally is considered to be possible for a net primary production when $Z_{\mathrm{m}} / Z_{\mathrm{eu}}$ is 5-6 or lower (Cole and Cloern 1984; Grobbelaar 1985; Irigoien and Castel 1997). For the upper East River tidal strait, in the deep central channel ( $24 \mathrm{~m}$ depth), the $Z_{\mathrm{m}} / Z_{\mathrm{eu}}$ was great than 6 for the sample period; therefore, it is likely that the central channel would not have net primary production to initiate a phytoplankton bloom. In the south channel with a depth of $15 \mathrm{~m}, Z_{\mathrm{m}} / Z_{\mathrm{eu}}$ was close to 5 in June/July and it is barely low enough for a bloom to initiate; whereas in September/October $Z_{\mathrm{m}} / Z_{\text {eu }}$ was 2.5 suggesting that there was enough light for a net primary production.

The high suspended solids and shallow euphotic zone at the study site had a noticeable effect on the growth of aquacultured macroalga. Kim et al. (2014) reported that the growth of Gracilaria tikvahiae McLachlan at the site declined from just $0.5 \mathrm{~m}$ below surface to $2.5 \mathrm{~m}$ depth, with maximum growth near the surface. The higher nitrogen and lower carbon content at the depth implied slower photosynthetic rates beneath $0.5 \mathrm{~m}$ depth.

The present study provides evidence that phytoplankton community photosynthesis was light-limited in the East River tidal strait. Whether or not phytoplankton photosynthesis and growth were sufficient to maintain the population on the site cannot, however, be ascertained from the data. Other factors contributing to the answer are: phytoplankton respiration rates, loss to grazing by zooplankton and other grazers, and gain or loss through water exchange (Wofsy 1983; Cole et al. 1992). In two previously studied environments, the turbid upper Hudson River and San Francisco Bay, phytoplankton respiration alone was shown to exceed photosynthesis in well-mixed areas (Alpine and Cloern 1988; Lewis 1988; Cole et al. 1992). In these systems, phytoplankton relied upon external input (immigration) to maintain biomass.

In contrast to most high-nutrient estuaries, the East River tidal strait has low chlorophyll concentrations. Our results suggested that the phytoplankton at the site were not able to produce net primary productivity at least part of the year because of the low light penetration in the water. We speculate, therefore, that the low chlorophyll at the site was caused by low in situ phytoplankton growth rates rather than loss of biomass through grazing, sinking, or horizontal transport.

Driven largely by water column photosynthesis and respiration, dissolved oxygen (DO) and $\mathrm{pH}$ of a productive coastal system usually exhibited one peak and one valley over a diel cycle (e.g., Li et al. 2012). In contrast, the East River tidal strait exhibited two peaks and two valleys in DO and pH over a diel cycle suggesting that tidal rather than biological activities (photosynthesis and respiration) played a major role. The effect of tidal influence on DO and $\mathrm{pH}$ is also witness by the significant, although weak, correlation between tidal height and $\mathrm{DO}$, tidal height and $\mathrm{pH}$, for most of the time periods (Table 1).

The Western Long Island Sound (WLIS), adjacent to the East River tidal strait, has exhibited seasonal hypoxia in the bottom water for decades (Parker and O'Reilly 1991; O'Donnel et al. 2014). The most common belief for the cause of hypoxia is that phytoplankton in the WLIS respond to the high loading of nitrogen and phosphorous from various sources. Seasonal stratification is thought to allow greater residence of phytoplankton in the upper euphotic zone. Thus, hypoxia develops when bacteria consume and respire the supply of 
phytoplankton and oxygen, particularly in the summer. The relaxation of stratification in the fall allows reoxygenation of bottom waters. There are also indications that phytoplankton in the WLIS may be nutrientlimited, particularly in the summer. For example, Anderson and Taylor (2001) reported that phytoplankton production in the WLIS responded to the input of ammonia from rain events, and the severity of hypoxia also was coupled with ammonia pulses related to rain events.

Although there is a net flow of surface water from the East River tidal strait toward the WLIS (Bowman 1976; Browning et al. 2014), the East River tidal strait cannot be a significant source of phytoplankton biomass to WLIS because chlorophyll $a$ levels in the East River tidal strait are much lower than those observed in the WLIS. The East River tidal strait with high nutrient concentrations, however, certainly can provide net nutrient input to the WLIS where light penetrations was higher to support phytoplankton growth. As the net tidal flow fluctuates on a weekly basis following the lunar cycle, nutrient input to the WLIS likely also fluctuates on a weekly basis. Coincidentally, hypoxia in WLIS was shown to oscillate on a weekly basis (Anderson and Taylor 2001). Thus, there is likely cause and effect between the nutrient input from East River tidal strait and the dynamics of hypoxia in the WLIS.

Acknowledgements The following individuals are appreciated for participating the field work: Genevieve Bernatchez, Eve Gallimony, Julie Rose, Marguerite Petit, and Aynur Lok. Matt Lyman of the CT Department of Environmental Protection and Energy (DEEP) is acknowledged for making available the Long Island Sound Monitoring Program data. We thank LTJG Erick Estela for providing the ArcView map of the study site. This study was supported by the NOAA Office of Aquaculture and NOAA Fisheries Northeast Fisheries Science Center. Brian Gionado was very accommodating for our field work at his construction site and he is appreciated for making one of his trailers available to us for fluorescence measurements in the dark.

Open Access This article is distributed under the terms of the Creative Commons Attribution 4.0 International License (http:// creativecommons.org/licenses/by/4.0/), which permits unrestricted use, distribution, and reproduction in any medium, provided you give appropriate credit to the original author(s) and the source, provide a link to the Creative Commons license, and indicate if changes were made.

\section{References}

Alpine AE, Cloern JE (1988) Phytoplankton growth rates in a light-limited environment, San Francisco Bay. Mar Ecol Progress Series Oldendorf 44:167-173

Anderson TH, Taylor GT (2001) Nutrient pulses, plankton blooms, and seasonal hypoxia in western Long Island Sound. Estuaries 24:228-243

Behrenfeld MJ, Zbigniew K (1999) Widespread iron limitation of phytoplankton in the South Pacific ocean. Science 283:840-843

Blumberg AF, Pritchard DW (1997) Estimates of the transport through the East River, New York. J Geophys Res C: Oceans 102:5685-5703

Bowman MJ (1976) The tides of the East River, New York. J Geophys Res 81:1609-1616

Browning TJ, Bouman HA, Moore CM, Schlosser C, Tarran GA, Woodward EMS, Hender Son GM (2014) Nutrient regimes control phytoplankton ecophysiology in the South Atlantic. Biogeosciences 11:463-479

Capriulo GM, Smith G, Troy R, Wikfors GH, Pellet J, Yarish C (2002) The planktonic food web structure of a temperate zone estuary, and its alteration due to eutrophication. Hydrobiologia 475:263-333

Chekalyuk A, Hafez M (2008) Advanced laser fluorometry of natural aquatic environments. Limnol Oceanogr Methods 6:591-609

Cloern JE (1987) Turbidity as a control on phytoplankton biomass and productivity in estuaries. Cont Shelf Res 7:1367-1381

Cole BE, Cloern JE (1984) Significance of biomass and light availability to phytoplankton productivity in San-Francisco bay. Mar Ecol Prog Ser 17:15-24

Cole JJ, Caraco NF, Peierls BL (1992) Can phytoplankton maintain a positive carbon balance in a turbid, freshwater, tidal estuary? Limnol Oceanogr 37:1608-1617

Dandonneau Y, Neveux J (1997) Diel variations of in vivo fluorescence in the eastern equatorial Pacific: an unvarying pattern. Deep-Sea Research Part II-Topical Stud Oceanogr 44:1869-1880

Domingues RB, Anselmo TP, Barbosa AB, Sommer U, Galvao HM (2011a) Light as a driver of phytoplankton growth and production in the freshwater tidal zone of a turbid estuary. Estuar Coast Shelf Sci 91:526-535

Domingues RB, Anselmo TP, Barbosa AB, Sommer U, Galvao HM (2011b) Nutrient limitation of phytoplankton growth in the freshwater tidal zone of a turbid, Mediterranean estuary. Estuar Coast Shelf Sci 91:282-297

Galimany E, Rose JM, Dixon MS, Wikfors GH (2013) Quantifying feeding behavior of ribbed mussels (Geukensia demissa) in two urban sites (Long Island Sound, USA) with different seston characteristics. Estuaries Coasts 36:1265-1273

Gameiro C, Zwolinski J, Brotas V (2011) Light control on phytoplankton production in a shallow and turbid estuarine system. Hydrobiologia 669:249-263 
Goeyens L, Kindermans N, Yusuf MA, Elskens M (1998) A room temperature procedure for the manual determination of urea in seawater. Estuar Coast Shelf Sci 47:415-418

Goto N, Kihira M, Ishida N (2008) Seasonal distribution of photosynthetically active phytoplankton using pulse amplitude modulated fluorometry in the large monomictic Lake Biwa, Japan. J Plankton Res 30:1169-1177

Grobbelaar JU (1985) Phytoplankton productivity in turbid waters. J Plankton Res 7:653-663

Hansen H, Koroleff F (1999) Determination of nutrients. In: Grasshoff K, Kremling K, Ehrhardt M (eds) Methods of seawater analysis. Wiley-VCH, Weinheim, pp 158-228

Harding LW, Meeson BW Jr, Fisher TR Jr (1986) Phytoplankton production in two East Coast estuaries: photosynthesis-light functions and patterns of carbon assimilation in Chesapeake and Delaware bays. Estuar Coast Shelf Sci 23:773-806

Hasle GR (1978) The inverted microscope method. In: Sournia A (ed) Phytoplankton manual. UNESCO, Paris, pp 88-96

Holmes RW (1970) The secchi disk in turbid coastal waters. Limnol Oceanogr 15:688-694

Irigoien X, Castel J (1997) Light limitation and distribution of chlorophyll pigments in a highly turbid estuary: the Gironde (SW France). Estuar Coast Shelf Sci 44:507-517

Johnson ZI, Shyam R, Ritchie AE, Mioni C, Lance VP, Murray JW, Zinser ER (2010) The effect of iron- and light-limitation on phytoplankton communities of deep chlorophyll maxima of the western Pacific Ocean. J Mar Res 68:283-308

Kim JK, Kraemer GP, Yarish C (2014) Field scale evaluation of seaweed aquaculture as a nutrient bioextraction strategy in Long Island Sound and the Bronx River Estuary. Aquaculture 433:148-156

Kocum E, Underwood GJC, Nedwell DB (2002) Simultaneous measurement of phytoplanktonic primary production, nutrient and light availability along a turbid, eutrophic UK east coast estuary (the Colne Estuary). Mar Ecol Prog Ser 231:1-12

Kromkamp J, Peene J, Van Rijswijk P, Sandee A, Goosen N (1995) Nutrients, light and primary production by phytoplankton and microphytobenthos in the eutrophic, turbid Westerschelde Estuary (The Netherlands). Hydrobiologia 311:9-19

Lewis WM Jr (1988) Primary production in the Orinoco River. Ecology 69:679-692

Li Y, Veilleux DJ, Wikfors GH (2009) Particle removal by Northern bay scallops Argopecten irradians irradians in a seminatural setting: application of a flow-cytometric technique. Aquaculture 296:237-245

Li Y, Meseck SL, Dixon MS, Rivara K, Wikfors GH (2012) Temporal variability in phytoplankton removal by a commercial, suspended eastern oyster nursery and effects on local plankton dynamics. J Shellfish Res 31:1077-1089

Li Y, Meseck SL, Dixon MS, Rose JM, Smith BC, Wikfors GH (2013) Short term effects of a commercial eastern oyster nursery upon nutrient and plankton dynamics of a coastal embayment: observations from mesocosm experiments. Aquac Res 46:2049-2064

Liu S, Lin S (2008) Temporal and spatial variation of phytoplankton community in Long Island Sound Proceedings of the The 9th Biennial Long Island Sound Research Conference, 2008, 28-34

Lopez G, Carey D, Carlton JT, Cerrato R, Dam H, Digiovanni R, Elphick C, Michael F, Gobler C, Hice L, Howell P, Jordaan A, Lin S, Liu S, Lonsdale D, Mcenroe M, Mckown K, Mcmanus G, Orson R, Peterson B, Pickerell C, Rozsa R, Shumway SE, Siuda A, Streich K, Talmage S, Taylor G, Thomas E, Van Patten M, Vaudrey J, Yarish C, Wikfors GH, Zajac R (2014) Biology and ecology of Long Island sound. In: Latimer J, Tedesco MA, Swanson RL, Yarish C, Stacey PE, Garza C (eds) Long island sound prospects of the urban sea. Springer, New York, pp 285-479

Marmer HA (1935) Tides and currents in New York Harbor (Special Publication)

Mcminn A, Pankowskii A, Ashworth C, Bhagooli R, Ralph P, Ryan K (2010) In situ net primary productivity and photosynthesis of Antarctic sea ice algal, phytoplankton and benthic algal communities. Marine Biology 1345-1356

Meseck SL, Li Y, Dixon MS, Rivara K, Wikfors GH, Luther GI (2012) Effects of a commercial, suspended eastern oyster nursery upon nutrient and sediment chemistry in a temperate, coastal embayment. Aquac Environ Interact 3:65-79

Nixon SW (1995) Coastal marine eutrophication: a definition, social causes, and future concerns. Ophelia 41:199-219

O'donnel J, Wilson RE, Lwiza K, Whitney M, Bohlen WF, Codiga D, Fribance DB, Fake T, Bowman M, Varekamp JC (2014) The physical oceanography of Long Island Sound. In: Latimer J, Tedesco MA, Swanson RL, Yarish C, Stacey PE, Garza C (eds) Long Island sound prospects of the Urban Sea, New York, Heidelberg

Parker CA, O'reilly JE (1991) Oxygen depletion in Long Island sound: a historical perspective. Estuaries 14:248-264

Pourafrasyabi M, Ramezanpour Z (2014) Phytoplankton as bio-indicator of water quality in Sefid Rud River, Iran (South of Caspian Sea). Caspian J Environ Sci 12:31-40

Throndsen J (1978) Preservation and storage. In: Sournia A (ed) Phytoplankton manual. UNESCO, Paris, pp 69-74

Underwood GJC, Kromkamp J (1999) Primary production by phytoplankton and microphytobenthos in estuaries. Adv Ecol Res 29:93-153

Varekamp JC, Mcelroy AE, Mullaney JR, Breslin VT (2014) Metals, organic compounds, and nutrients in Long Island Sound: sources, magnitudes, trends, and impacts. In: Latimer J, Tedesco MA, Swanson RL, Yarish C, Stacey PE, Garza C (eds) Long Island sound prospects of the Urban sea. Springer, New York, pp 203-283

Wofsy SC (1983) A simple model to predict extinction coefficients and phytoplankton biomass in eutrophic waters. Limnol Oceanogr 28:1144-1155

Yamane Y, Utsunomiya T, Watanabe M, Sasaki K (2001) Biomass production in mixotrophic culture of Euglena gracilis under acidic condition and its growth energetics. Biotech Lett 23:1223-1228

\section{Publisher's Note}

Springer Nature remains neutral with regard to jurisdictional claims in published maps and institutional affiliations. 